\title{
Service Quality of Air KBZ
}

\author{
Khin Thet Htwe* 1 \\ ${ }^{1}$ Department of Economics \\ Mandalay University of Distance Education, Mandalay. \\ *Corresponding author: khinthethtwe33@gmail.com
}

\begin{abstract}
The objectives of the study are to identify the service quality of Air KBZ in Mandalay and to analyze the relationship between service quality and customer satisfaction of Air KBZ in Mandalay. Both primary data and secondary data are used. This study selected 156 respondents who fled over two times with Air KBZ by using convenience sampling method. Descriptive statistics are used to describe the profile of the respondents. Correlation and multiple regression analysis are applied to analyze the relationship between service quality (airline tangibles, personnel, empathy and image) and customer satisfaction of Air KBZ in Mandalay. The results discovered that airline tangibles, personnel, empathy and image are positively and strongly correlated with customer satisfaction. The results found that airline tangibles, personnel and image are significantly effect on customer satisfaction. Unfortunately, empathy is not significant effect on customer satisfaction. As such, it is to suggest that airline tangibles, personnel and image continuously need to be performed by Air KBZ company present and future to satisfy customer. The result will help services offered by Air KBZ has positive impact and are significant in building customer satisfaction. It is recommended that the quality of service quality should be made the best quality so that customers are able to use undoubtedly without anxieties.
\end{abstract}

Keywords: Airline Tangibles, Customer Satisfaction, Empathy, Image, Personnel

\section{Introduction}

Tourism has emerged as one of the major global economic businesses in the $21^{\text {st }}$ century. It can be understood as a process of individuals or groups travelling from one place to another to gain pleasure or business experience. The tourism industry can only operate with the availability of other tourism essentials such as transportation, accommodation, entertainment, food and so on. Transportation is the most important contributor to the tourism industry. In general the main function of transportation is transit, carrying people and goods from one destination to another. Airline industry is one the hospitability sector which to expect to provide the best service to customer (Nameghi \& Ariffin, 2013). Air travel is a tourism product with high demand; this results in a strong competition among airlines leading the air travel industry to a constant effort to improve service quality in order to meet customer's needs (Shukla, 2013). People use transportation services to travel from one place to another seeking tourism or to deliver tourism goods. Transportation is the most essential components of the tourism industry. Travel and tours sector not only plays in a significant factor but also acts an integral part of development of the country. As there are various choices in the market, customer can make comparison before they buy the ticket. Air transportation has reduced the time required to travel from long to short time and 
Borneo Journal of Social Science \& Humanities

DOI: https://doi.org/10.35370/bjssh.2021.3.2-06

e-ISSN: 2682-8235

(C) 2018, UCTS Publisher

Submitted: 25 September 20212021

Accepted: 21 December 2021

Published: 31 December 2021

boosted the long-distance trips and has become the most popular mode of travel in modern society. Recently the share of air transportation in the transportation market has grown significantly and has not only made an impact upon the tourism industry and developed countries, but it has made a huge impact upon developing countries and their economy.

As the world is changing rapidly and very competitive, airlines industry become one of the most important roles of economic development. Airline industries in Myanmar have been facing high competition among many competitors who can provide similar quality of the services. Every airlines needs to maintain the current customers and also need to get new customers. Then, receiving the expectation of customers is also improved to make the quality of service for airline industry that will make airline work hard and think to solve new ways to convenient for making customers satisfied. Therefore, to survive in airlines industry, passengers' satisfaction is the most important in airlines industry. Air transport is one of the world's most important industries and it is also the global network of commercial aircraft operators, airports, air navigation service providers and the manufacturers of aircraft and their components.

Myanmar domestic carriers are now struggling to compete in Myanmar aviation market. According to Centre for Asia Pacific Aviation's recent report, both domestic and international markets are oversupplied and this has impacted on load factors and profitability. Myanmar has five domestic airlines: Myanmar National Airlines, Air KBZ, Yangon Airways, Golden Myanmar Airlines and Man Yadanarpon Airlines. Air KBZ is one of the most critical service companies in Myanmar that customers are mostly facing dissatisfaction. Airlines companies are trying to maximize service quality and present new services to attract more of passengers' attention. This study emphasizes on service quality and customer satisfaction of Air KBZ in Mandalay. The objectives of the study are to identify the service quality of Air KBZ in Mandalay and to analyze the relationship between service quality and customer satisfaction of Air KBZ in Mandalay.

\section{Literature Review}

Service is defined as social act which takes places in direct contact between the customer and representatives of the service company (Quinn \& Gagnon, 1986). The unique characteristics of pure services include (1) intangibility of services, (2) inseparability/simultaneity of production from consumption, where customers are also involved in the production of services, (3) perishability of services, where services not consumed are lost, and (4) heterogeneity/variability in service products, where services provided by the same person may differ between customers or differ at different times (McColl, Carlson, Johnston, Minnes, Shue, Davies, \& Karlovits, 1998).

\section{Airline Tangibles}

The first AIRQUAL dimension is called airline tangibles and is often acknowledged as one of the most important dimensions in order to satisfy passengers in the airline industry. It includes items relating to the overall condition of the aircraft. In this dimension, it is mainly asked for airline tangible elements that can be associated with the service quality of an airline, which comprise the quality of the equipment of the airplane, the comfort of the seats and the cleanliness of the interior (Farooq, Hao, \& Liu, 2018).

Airline tangibles cover the appearance of the physical facilities, equipment and communication materials and all are physical evidence of the services. Because of airline tangibles, 
Submitted: 25 September 20212021

Accepted: 21 December 2021

Published: 31 December 2021

passenger can provide the physical evidence of the services and which can be applied as the evaluation of the service quality (Zeithaml, Bitner, \& Gremler, 2006). Tangibility is the physical conveniences, equipment and appearance of personality (Parasuraman, Zeithaml, \& Berry, 1998).

\section{Personnel}

The personnel play an important role in the provision of a service because personnel are the ones that contact to the passengers (Babbar \& Koufteros, 2008). Each interaction between customer and employee gives the employee the opportunity to satisfy or dissatisfy the passenger (Ringle, Sarstedt, \& Zimmermann, 2011). According to Employees of the airlines is crucial part of the determination of the customers' satisfaction level (Babbar \& Koufteros, 2008). The personnel dimension of service quality examines the quality of the contact employees provide to the customer (Farooq et al., 2018).

\section{Empathy}

Empathy is defined as the ability of an airline gate attendant to make a customer's missed connection the attendant's own problem and to find a solution (Fitzsimmons \& Fitzsimmons, 2011). Empathy, which poses questions like; punctuality of the departures and arrivals, transportation between city and airport, compensation schemes in case of loss or hazard, care paid to passengers' luggage, availability of health personnel during the flights, locations of the airline company offices, convenient schedules for passengers, number of flights to satisfy passengers' demands (Nadiri, Nourani, \& Mogaddam, 2008). Empathy has been found to be a driver for customer satisfaction in other studies (Moslehpour, Wong, Van Pham, \& Aulia, 2017).

\section{Image}

The image of the airline seems to play a relevant role in the passengers' evaluation of the service quality (Gronroos, 1994). The image dimension of the AIRQUAL scale contains items such as promotional offers, value for money or the overall perception of the airline's image (Farooq et al., 2018). The image to a passenger has of an airline influences both loyalty and customer satisfaction (Forgas, Moliner, Sánchez, \& Palau, 2010). Unlawful interference could be acts of terrorism, sabotage, threat to life and property, communication of false threat, bombing, etc. (Lee, 2009). Image is considerably influences quality and trust by consumers such as on time departure and arrival, safety record and reasonable ticket fares (Bari et al., 2001).Image is based on the customer's beliefs upon a brand. Image defined as the sum of beliefs, ideas and impression (Keller, 1993). Image has a significant impact upon the customer satisfaction and loyalty (Groonros, 1994).

\section{Conceptual Framework}

There are five dimensions of AIRQUAL dimensions in airlines service quality including airlines tangibles, terminal tangibles, personnel, empathy and image. It was used only four independent variables; airline tangibles, personnel, empathy and image to measure airline service quality in this study. 
Independent Variables

Dependent Variable

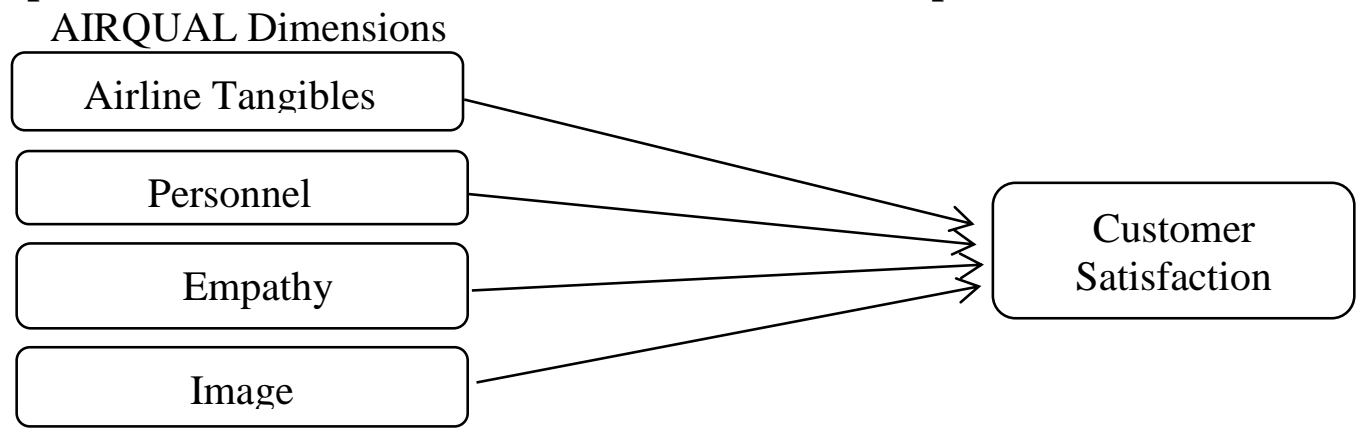

Figure 1 Conceptual Framework

Source: Author

\section{Methodology}

This study focuses on customer satisfaction on service quality and Air KBZ in Mandalay. The sample respondents were collected by convenience sampling method because it was not possible to reach the population. Data collection period was in January 2020. Questionnaire items were measured by Five-point Likert Scale. Both primary and secondary data were used in this study. Primary data were collected from 156 respondents who flew over two times with Air KBZ using structured questionnaire. A questionnaire was designed to study the AIRQUEAL scale for measuring airline service quality and its effect on customer satisfaction. Secondary data were gathered from relevant text books, previous studies and Air KBZ official website. Descriptive statistic was used to describe the profile of the respondents. Correlation and multiple regressions analysis were used to analyze the relationship between service quality and customer satisfaction of Air KBZ in Mandalay. This study uses multiple regression analysis using Statistical Package for Social Science (SPSS) software.

Airlines tangibles is measured by interior of airplanes, seat, in flight-entertainment, toilet, air condition in the plane and meal service. Personnel is measured by attitude of staff, experience and education of staff, prompt check service, knowledge of staff, responsive attitude of staff for complaints and friendly and staff willingness. Empathy is measured by compensation of damage, good care to luggage, flight schedules, flight departure and arrival, sharing information, polite crew. Image is measured by ticket price, promotion, and availability of appealing seat, safety record, security and flight amendment.

\section{Findings}

\section{Respondents' Demographic Profile}

SPSS statistical tool was used to test the proposed hypotheses and assess the validity of the constructs in this study. A complete demographic profile of the respondents is shown in Table 1. 
Borneo Journal of Social Science \& Humanities

DOI: https://doi.org/10.35370/bjssh.2021.3.2-06

e-ISSN: 2682-8235

(C) 2018, UCTS Publisher

Submitted: 25 September $20212021 \quad$ Accepted: 21 December 2021

Published: 31 December 2021

Table 1 Demographic Characteristics of the Respondents $(N=156)$

\begin{tabular}{|c|c|c|c|}
\hline Profile & Category & Frequency & Percentage \\
\hline \multirow[t]{2}{*}{ Gender } & Male & 100 & 64.10 \\
\hline & Female & 56 & 35.90 \\
\hline \multirow[t]{4}{*}{ Age (Years) } & Under 20 and 20 & 10 & 6.41 \\
\hline & $21-30$ & 49 & 31.41 \\
\hline & $31-40$ & 51 & 32.70 \\
\hline & Above 40 & 46 & 29.48 \\
\hline \multirow[t]{2}{*}{ Marital Status } & Single & 73 & 46.79 \\
\hline & Married & 83 & 53.21 \\
\hline Education & High School & 6 & 3.85 \\
\hline \multirow[t]{3}{*}{ Level } & Undergraduate & 3 & 1.92 \\
\hline & Graduate & 111 & 71.15 \\
\hline & Postgraduate & 36 & 23.08 \\
\hline \multirow[t]{5}{*}{ Occupation } & Student & 1 & 0.64 \\
\hline & Government Servant & 21 & 13.46 \\
\hline & Private Enterprises & 71 & 45.51 \\
\hline & Own Business & 57 & 36.54 \\
\hline & Unemployed & 6 & 3.85 \\
\hline \multirow{5}{*}{$\begin{array}{l}\text { Income Level } \\
\text { (Kyats) }\end{array}$} & Less than 300,000 and 300,000 & 5 & 3.21 \\
\hline & $300,001-500,000$ & 21 & 13.46 \\
\hline & $5000,001-700,000$ & 37 & 23.72 \\
\hline & $700,001-900,000$ & 60 & 38.46 \\
\hline & More than 900,000 & 33 & 21.15 \\
\hline \multirow{4}{*}{$\begin{array}{l}\text { Reason for } \\
\text { Travelling }\end{array}$} & Business & 81 & 51.92 \\
\hline & Meeting & 11 & 7.05 \\
\hline & Vacation & 35 & 22.44 \\
\hline & Other (personal matters) & 29 & 18.59 \\
\hline \multirow{7}{*}{$\begin{array}{l}\text { Reasons for } \\
\text { choosing Air } \\
\text { KBZ }\end{array}$} & Ticket Fares & 24 & 15.38 \\
\hline & Flight schedule & 40 & 25.64 \\
\hline & Airlines reputation & 21 & 13.46 \\
\hline & Easy online booking & 8 & 5.13 \\
\hline & Responsive customer service & 32 & 20.51 \\
\hline & Taking advice from ticketing agent & 25 & 16.03 \\
\hline & Other & 6 & 3.85 \\
\hline
\end{tabular}

Source: Author

The questionnaire contained a range of questions to determine the respondents' characteristics. Gender of respondents is divided into two groups, male and female who enjoyed service with Air KBZ. Table 1 presents that 64.10 percent of respondents are male and 35.90 percent of respondents are female. Of 156 respondents, 6.41 percent of respondents are under 20 years, 31.41 percent of respondents are 21-30 years, 32.70 percent of respondents are 31-40 years and lastly 29.48 percent of respondents are above 40 years. For marital status, approximately $46.79 \%$ of respondents are single and 53.21 percent of respondents are married. Academically, the highest percentage were graduate $(n=111,71.15 \%)$ followed by postgraduate holders $(n=36$, $23.08 \%)$ and high school $(n=6,3.85 \%)$. This level of educational attainment indicated that they were knowledgeable. In terms of occupation, 45.51 percent respondents were categorized as private enterprises. The second largest group was own business, which recorded 57 respondents. 
Submitted: 25 September $20212021 \quad$ Accepted: 21 December $2021 \quad$ Published: 31 December 2021

As for monthly income of respondents, the majority of respondents recorded a monthly income from 700,001-900,000 kyats, while 23.72 percent $(n=37)$ were within the range of 5000,001700,000 kyats followed by 21.15 percent $(n=33)$ who earned more than 900,000 kyats. Reasons for travelling are also analyzed in the present study. Approximately, 51.92 percent respondents are business purposes/trips $(n=81,51.92 \%), 22.44$ percent $(n=35)$ recorded for vacation, 18.59 percent $(n=29)$ for others (personal matters), and lastly only 7.05 percent $(n=11)$ were go for meeting. Approximately, 25.64 percent of respondents are preferred to use Air KBZ because of flight schedules, 20.51 percent of respondents are intended to use Air KBZ because responsive customer service followed by 16.03 percent of respondents are chosen Air KBZ because of taking advices from ticketing agents,

\section{Reliability Analysis of the Variables}

According to Best (1977), when the alpha value is between 0.89 and 0.95 , it is considered very good reliability, when alpha value is 0.7 and 0.89 is considered good reliability and when the alpha value is between 0.6 and 0.7 , it is considered as fair reliability and the alpha value is below 0.6 will be considered as poor quality.

\section{Table 2 Reliability Analysis}

\begin{tabular}{lcc}
\hline \multicolumn{1}{c}{ Variables } & No. of Items & Cronbach's Alpha \\
\hline Airline Tangibles & 6 & 0.882 \\
Personnel & 6 & 0.841 \\
Empathy & 6 & 0.882 \\
Image & 6 & 0.867 \\
Customer Satisfaction & 12 & 0.929 \\
\hline
\end{tabular}

Source: Author

As noted in Table 2, Cronbach's alpha value showed the alpha value of selected variables (airline tangible, personnel, empathy, and image). The result of Cronbach's alpha of airline tangible, personnel, empathy and image are between 0.8 and 0.9 which show good level. Therefore, the questionnaires scale items are consistent and reliable.

\section{Multiple Regression Analysis of Service Quality and Customer Satisfaction}

Multiple regression analysis was conducted to test the proposed objectives of the relationship between factors (airline tangibles, personnel, empathy and image) and customer satisfaction. The results of multiple regression analysis are shown in Table 3. 
Table 3: Multiple Regression Analysis of Service Quality and Customer Satisfaction

\begin{tabular}{|c|c|c|c|c|c|}
\hline \multirow[t]{2}{*}{ Model } & \multicolumn{2}{|c|}{ Unstandardized Coefficients } & \multirow{2}{*}{$\begin{array}{c}\text { Standardized } \\
\text { Coefficients }\end{array}$} & \multirow{2}{*}{$\mathrm{t}$} & \multirow{2}{*}{ Sig. } \\
\hline & B & Std. Error & & & \\
\hline (Constant) & -0.365 & 0.128 & & & \\
\hline Airline Tangibles & 0.411 & 0.050 & 0.413 & 8.194 & 0.000 \\
\hline Personnel & 0.292 & 0.058 & 0.267 & 5.011 & 0.000 \\
\hline Empathy & 0.096 & 0.052 & 0.099 & 1.859 & 0.065 \\
\hline Image & 0.283 & 0.038 & 0.289 & 7.389 & 0.000 \\
\hline $\mathrm{R}$ & & & & & 0.931 \\
\hline $\mathrm{R}^{2}$ & & & & & 0.866 \\
\hline Adjusted $\mathrm{R}^{2}$ & & & & & 0.862 \\
\hline
\end{tabular}

Note: $\mathrm{P}<0.01$ : Significant at 1 percent level

Dependent Variable: Customer Satisfaction

According to regression results, if the airline company had not provided the service quality (airline tangibles, personnel, empathy, and image) the customer satisfaction was 0.365. One additional unit of airline tangibles increases 0.411 in customer satisfaction. This implies that airline tangible is significantly related to customer satisfaction at 1 percent level. Besides, additional unit of personnel increases 0.292 in customer satisfaction. It means that personnel is significantly led to customer satisfaction at 1 percent level. One additional unit of empathy increases 0.096 in customer satisfaction. This implies that there is a positive effect of empathy and customer satisfaction at 1 percent level. One additional unit of image increases 0.283 in customer satisfaction. There is a positive effect of image and customer satisfaction at 1 percent level.

\section{Findings and Discussions}

This study focuses on service quality and customer satisfaction of Air KBZ. To analyze the customer perception on service quality (Airline Tangible, Personnel, Image, and Empathy) are conducted reliability analysis, correlation analysis, and regression analysis. The results of the multiple regression analysis of the service quality dimensions, (airline tangible, personnel and image) are significantly contribute to customer satisfaction in the Air KBZ. Among these variables, airline tangible is the most significant effect on customer satisfaction followed by the element of image. Personnel variable is third significant effect on customer satisfaction of the Air KBZ. It is to conclude that the customers are satisfied with experience and staff's education level that provided by Air KBZ. Unfortunately, empathy was negatively related to customer satisfaction. This is perhaps customers were unsatisfied with damage compensation. The findings showed that airline tangibles, personnel, and image were significant role to create customer satisfaction. From the research findings and the answers to the research questions, some conclusions can be made about the study. 
Borneo Journal of Social Science \& Humanities

DOI: https://doi.org/10.35370/bjssh.2021.3.2-06

e-ISSN: 2682-8235

(C) 2018, UCTS Publisher

Submitted: 25 September $20212021 \quad$ Accepted: 21 December 2021

Published: 31 December 2021

\section{Suggestions and Recommendations}

The results exposed that airline tangibles, personnel, and image are significantly contribute customer satisfaction, Air KBZ. This study contributes the company by suggestion ways to improve their customer satisfaction, comparing to other airlines. To maintain and satisfy the existing customers, new service factors need to get good quality to be provided more than service currently. If employees do not work according to standard operation procedure, management should provide regular training to airlines staff. Moreover, the airlines employees should provide the prompt customer service and give attention to the needs of customers. Air transportation is mainly service business and airlines staffs' service performance can directly effect on customers satisfaction.

If the airline provides service quickly and accurately, it can increase the reliability or reputation of the airlines. Flight delay on weather or technical errors, the customers need prompt information. Employee welfare such as, rewards and other benefits can motivate staffs' job performance. Insufficient knowledge of staff, poor communication with customers and bad nonverbal behaviors can effect customer satisfaction. Thus, Air KBZ should train more staff in order to give prompt information regarding flight times, delays and any general queries the customer has before boarding. Air KBZ's service quality is evaluated positively by respondents and the level of customer satisfaction is good. But Air KBZ should emphasize to enhance better service quality to fulfill customer satisfaction absolutely. According to this study, customer satisfaction is directly relationship with service quality delivered by Air KBZ. The results of this study also provide management with information regarding the importance of value creation and the allocation of resources in Myanmar air travel.

\section{Limitations and Conclusion}

This study only focuses on service quality and customer satisfaction on Air KBZ at Mandalay station. Some future research can be enlarged by means of continuous interviewing of customers or study at other stations of Air KBZ. Additionally, the collected sample consisted of passengers living in the Mandalay Division. Further studies should concentrate on a larger sample size and all types of domestic airlines at Mandalay International Airport. Besides, this study only measured the service quality of Air KBZ by using AIRQUAL model. The service quality of Air KBZ can be analyzed by using other models and techniques. This study included four dimensions: Tangibles, personnel, empathy and image. Therefore, another research would be needed to investigate the effects of other dimensions on service quality of Air KBZ at Mandalay station. Further research needs to be conducted to identify satisfaction with airline quality for different groups of passengers. Furthermore, new service quality dimensions and attributes need to be included to expand this research.

\section{References}

Babbar, S. \& Koufteros, X. (2008). The human element in airline service quality: contact personnel and the customer. International Journal of Operations \& Production Management, 804830. 
Borneo Journal of Social Science \& Humanities

DOI: https://doi.org/10.35370/bjssh.2021.3.2-06

e-ISSN: 2682-8235

(C) 2018, UCTS Publisher

Submitted: 25 September $20212021 \quad$ Accepted: 21 December 2021

Published: 31 December 2021

Best, J.W. (1977). Research in education $3^{\text {rd }}$ ed. NJ: Prentice-Hall.

Farooq, Q., Hao, Y., \& Liu, X. (2018). Understanding corporate social responsibility with crosscultural differences: A deeper look at religiosity. Corporate Social Responsibility and Environmental Management, 26(4), 965-971.

Fitzsimmons, J.R. \& Douglas, E.J. (2011). Interaction between feasibility and desirability in the formation of entrepreneurial intentions. Journal of business venturing, 26(4), 431-440.

Forgas, S., Moliner, M.A., Sánchez, J., \& Palau, R. (2010). Antecedents of airline passenger loyalty: Low-cost versus traditional airlines. Journal of Air Transport Management, 16(4), 229-233.

Grönroos, C. (1994). Managing customer relationships for profit: the dynamics of relationship quality. International journal of service industry management, 5(5), 21-38.

Keller, K.L. (1993). Conceptualizing, measuring, and managing customer-based brand equity. Journal of marketing, 57(1), 1-22.

Laming, C. \& Mason, K. (2014). Customer experience-An analysis of the concept and its performance in airline brands. Research in Transportation Business \& Management, 10, $15-25$.

Lee, M.C. (2009). Factors influencing the adoption of internet banking: An integration of TAM and TPB with perceived risk and perceived benefit. Electronic commerce research and applications, 8(3), 130-141.

McColl, M.A., Carlson, P., Johnston, J., Minnes, P., Shue, K., Davies, D., \& Karlovits, T. (1998). The definition of community integration: perspectives of people with brain injuries. Brain injury, 12(1), 15-30.

Moslehpour, M., Wong, W.K., Van Pham, K., \& Aulia, C.K. (2017). Repurchase intention of Korean beauty products among Taiwanese consumers. Asia Pacific Journal of Marketing and Logistics, 29(3), 569-588.

Nadiri, A.O., Nourani, V., \& Mogaddam, A.A. (2008). An ANN-based model for spatiotemporal groundwater level forecasting. Hydrological Processes. An International Journal, 22(26), 5054-5066.

Parasuraman, A., Zeithaml, V.A., \& Berry, L.L. (1998). A conceptual model of service quality and its implications for future research. Journal of marketing, 49(4), 41-50.

Quinn, J.B. \& Gagnon, C.E. (1986). Will services follow manufacturing into decline. Harvard Business Review, 64(6), 95-103.

Ringle, C.M., Sarstedt, M., \& Zimmermann, L. (2011). Customer satisfaction with commercial airlines: The role of perceived safety and purpose of travel. Journal of Marketing Theory and Practice, 19(4), 459-472.

Shukla, L. (2013). A Case Study on Customer Acquisition and Retention on the Airline Service Industry. Journal of Business and Management, 9(4), 15-33.

Zeithaml, V.A., Bitner, M.J., \& Gremler, D.D. (2006). Services marketing strategy. Wiley International Encyclopedia of Marketing. 